\title{
PROFIL GULA DARAH SEWAKTU (GDS) DAN GULA DARAH PUASA (GDP) PASIEN STROKE DENGAN DIABETES MELLITUS TIPE 2 YANG DI RAWAT INAP DI BAGIAN NEUROLOGI Prof. DR. R. D. KANDOU MANADO PERIODE JANUARI - DESEMBER 2011
}

\author{
${ }^{1}$ David Sengka \\ ${ }^{2}$ Denny Ngantung \\ ${ }^{2}$ Corry Mahama
}

\author{
${ }^{1}$ Kandidat Skripsi Fakultas Kedokteran Universitas Sam Ratulangi \\ ${ }^{2}$ Bagian Ilmu Kedokteran Komunitas Fakultas Kedokteran Universitas Sam Ratulangi \\ Email: davidsengka@yahoo.com
}

\begin{abstract}
Stroke is the number three killer right after heart diseases and cancer. Diabetes Mellitus is one of the modifiable risk factor of stroke. The goal of this research was to obtain the data profile of the random glucose level and the fasting glucose level in stroke patients diagnosed with type $2 \mathrm{DM}$. This research was a descriptive research with the subjects of the type 2 DM diagnosed patients with accountable random glucose level and fasting glucose level which were inpatient in Neurology Department of RSUP. Prof. R. D. Kandou Manado with a time period from January to December 2011. The sex, age, random glucose level and fasting glucose level profile were obtain from the data of medical records. There were 60 stroke patients who were also diagnosed with type 2 DM. Most of them were females (51.67\%) with age of 40 to 59 years old (50\%), and the most the fasting glucose level o $200 \mathrm{mg} / \mathrm{dl}(53.33 \%)$ and the random glucose level of $126 \mathrm{mg} / \mathrm{dl}(51.66 \%)$. Conclusions: The patients who were also diagnosed with type $2 \mathrm{DM}$ were mostly females with the age of 40 to 59 years old. The data profile of the random glucose level and the fasting glucose level in stroke patients were mostly diagnosed with type $2 \mathrm{DM}$. This data will be able to help to determine the actions in order to treat and also to prevent stroke in type 2 DM patients.
\end{abstract}

Key words: Stroke, Diabetes Mellitus, random glucose level, fasting glucose level

\begin{abstract}
Abstrak: Stroke merupakan pembunuh nomor tiga setelah penyakit jantung dan kanker. Salah satu faktor risiko stroke yang dapat dimodifikasi adalah diabetes mellitus. Tujuan penelitian ini adalah untuk memperoleh data profil gula darah sewaktu dan gula darah puasa pasien stroke dengan diabetes mellitus tipe 2. Penelitian ini menggunakan metode penelitian deskriptif, subyek penelitian adalah pasien stroke dengan diabetes mellitus tipe 2 yang mempunyai hasil pemeriksaan gula darah sewaktu dan gula darah puasa dan di rawat inap di Bagian Neurologi BLU RSUP Prof. Dr. R. D. Kandou Manado periode Januari - Desember 2011. Jenis kelamin, Usia, Kadar gula darah sewaktu dan gula darah puasa dicatat dari data rekam medik. Terdapat 60 pasien yang mengalami stroke dengan diabetes mellitus tipe 2, sebagian besar adalah perempuan (51,67\%), umur $40-59$ (50\%), kadar gula darah sewaktu terbanyak $\geq 200 \mathrm{mg} / \mathrm{dl}$ $(53,33 \%)$, kadar gula darah puasa terbanyak $\geq 126(51,66 \%)$. Simpulan : Pasien stroke dengan diabetes mellitus tipe 2 didapatkan lebih banyak pada perempuan dengan usia 40 - 59 tahun. Profil gula darah sewaktu (GDS) dan gula darah puasa (GDP) terbanyak pada kategori terdiagnosis diabetes mellitus. Data ini dapat membantu menentukan kebijakan dalam upaya pencegahan dan penatalaksanaan stroke dengan diabetes mellitus tipe 2 .
\end{abstract}

Kata Kunci : Stroke, Diabetes Mellitus, gula darah sewaktu, gula darah puasa 
Stroke adalah gangguan fungsi sistem saraf yang terjadi mendadak dan disebabkan oleh gangguan peredaran darah otak. Stroke terjadi akibat gangguan pembuluh darah di otak. Gangguan pembuluh darah otak dapat berupa tersumbatnya pembuluh darah otak atau pecahnya pembuluh darah di otak. Otak yang seharusnya mendapat pasokan oksigen dan zat makanan menjadi terganggu. Kekurangan pasokan oksigen ke otak akan memunculkan kematian sel saraf. ${ }^{1}$ Di Indonesia, setiap 1000 orang, 8 orang diantaranya terkena stroke. Stroke merupakan penyebab kematian pada semua umur, dengan proporsi, 15,4\%. Setiap 7 orang yang meninggal di Indonesia, 1 diantaranya karena stroke. ${ }^{2}$ Menurut penelitian epidemiologi yang sampai saat ini dilaksanakan di Indonesia, kekerapan diabetes di Indonesia berkisar antara 1,4 dengan 1,6\%, kecuali di dua tempat yaitu di Pekajangan, suatu desa dekat Semarang 2,3\% dan di Manado $6 \% .{ }^{3}$ Kasus stroke baru terjadi pada 100 sampai 300 orang per 100.000 penduduk per tahun. Stroke merupakan pembunuh nomor tiga setelah penyakit jantung dan kanker ${ }^{1}$ Pengetahuan dan kepedulian tentang faktor risiko stroke anak sangat membantu upaya pencegahan dan pengendalian stroke. ${ }^{4}$ Salah satu faktor resiko stroke adalah diabetes mellitus (DM) yang dijumpai pada $15-20 \%$ populasi usia muda. Diabetes merupakan salah satu faktor risiko stroke iskemik yang utama. Diabetes akan meningkatkan risiko stroke dua kali lipat. Peningkatan kadar gula darah berhubungan lurus dengan risiko stroke ${ }^{1}$ Pada diabetes juga penegakan diagnosis harus didasarkan atas pemeriksaan kadar glukosa darah. Pada pasien diabetes mellitus tipe 2 juga terdapat kriteria khusus dalam penegakan diagnosis khususnya pada pmeriksaan gula darah sewaktu (GDS) dan gula darah puasa (GDP), dimana pada pemeriksaan glukosa darah sewaktu $\geq 200 \mathrm{mg} / \mathrm{dl}$ sudah cukup untuk menegakan diagnosis DM dan untuk hasil pemeriksaan glukosa darah puasa $\geq 126 \mathrm{mg} / \mathrm{dl}$ juga dapat digunakan untuk patokan diagnosis DM. ${ }^{5}$

\section{METODE PENELITIAN}

Penelitian ini bersifat deskriptif yang dilakukan di bagian Neurologi BLU RS Prof. dr. R. D. Kandou Manado dengan pengambilan data di bagian rekam medik BLU RS Prof. dr. R. D. Kandou Manado selama bulan November Desember 2012. Dengan subjek penelitian semua pasien stroke dengan riwayat diabetes mellitus dan yang di diagnosis diabetes mellitus saat datang yang mempunyai hasil pemeriksaan kadar GDS dan GDP periode Januari - Desember 2011. Alat bahan yang digunakan berupa literatur - literatur sebagai teori, rekam medik yang lengkap terutama yang disertai profil glukosa darah pasien, alat tulis menulis serta media elektronik. Dengan variabel penelitian pasien stroke dengan DM, usia, jenis kelamin, dan kadar glukosa darah. Pengambilan data dilakukan dengan mencatat data pasien yang terdiagnosis stroke yang dirawat inap di bagian Neurologi BLU RS Prof. dr. R. D. Kandoun Manado periode Januari - Desember 2011, serta mencari menegelompokan pasien berdasarkan variabel penelitian (dilihat dari rekam medik). Kemudian diolah dan dianalisis.

\section{HASIL DAN PEMBAHASAN}

Dari hasil pengumpulan data juga mengenai distribusi penyakit stroke berdasarkan jenis kelamin di bagian 
Neurologi RSUP Prof. DR. R. D. Kandou Manado periode Januari - Desember 2011, didapatkan bahwa jumlah pasien stroke dengan diabetes mellitus tipe 2 berjenis kelamin perempuan sebanyak 31 orang dari 60 data pasien (51,67\%).

Tabel 1. Pasien stroke dengan diabetes mellitus tipe 2 berdasarkan jenis kelamin

\begin{tabular}{ccc}
\hline Jenis kelamin & Jumlah & Presentase (\%) \\
\hline Laki-laki & 29 & 48,33 \\
\hline Perempuan & 31 & 51,67 \\
\hline Jumlah & 60 & 100 \\
\hline
\end{tabular}

Tabel 2. Stroke dengan diabetes mellitus tipe 2 berdasarkan usia

\begin{tabular}{ccc}
\hline Usia & Jumlah & Presentase (\%) \\
\hline $20-39$ & 4 & 6,67 \\
\hline $40-59$ & 30 & 50 \\
\hline $60-79$ & 23 & 38,33 \\
\hline$\geq 80$ & 3 & 5 \\
\hline Jumlah & 60 & 100 \\
\hline
\end{tabular}

Tabel 3. Pasien stroke dengan diabetes mellitus tipe 2 berdasarkan pemeriksaan kadar Gula Darah Sewaktu (GDS) dan Gula Darah Puasa (GDP)

\begin{tabular}{lccc}
\hline Variabel & Nilai (mg/dl) & Jumlah & Presentase (\%) \\
\hline $\begin{array}{l}\text { Gula darah sewaktu } \\
\text { (GDS) }\end{array}$ & $<110$ & - & - \\
\cline { 2 - 4 } & $110-199$ & 28 & 46,67 \\
\cline { 2 - 4 } & $\geq 200$ & 32 & 53,33 \\
& $<110$ & 19 & 31,67 \\
\hline $\begin{array}{l}\text { Gula darah puasa } \\
\text { (GDP) }\end{array}$ & $110-125$ & 10 & 16,67 \\
\end{tabular}


Dari hasil pengumpulan data didapatkan penderita yang terdiagnosis stroke paling banyak adalah pasien dengan kelompok umur 40 - 59 tahun yaitu sebanyak 30 orang dari 60 data pasien (50\%).

Berdasarkan hasil pengumpulan data didapatkan bahwa pada pemeriksaan GDS dan GDP yang dilakukan pada pasien stroke dengan diabetes mellitus tipe 2 umumnya pada pemeriksaan kadar gula darah sewaktu terbanyak adalah $\geq 200$ $\mathrm{mg} / \mathrm{dl}$ dengan jumlah 32 orang atau sekitar (53,33\%) dan pada pemeriksaan kadar gula darah puasa terbanyak adalah $\geq$ $126 \mathrm{mg} / \mathrm{dl}$ dengan jumlah 31 orang atau sekitar (51,66\%)

Dari hasil pengumpulan data juga mengenai distribusi penyakit stroke berdasarkan jenis kelamin di bagian Neurologi RSUP Prof. DR. R. D. Kandou Manado periode Januari - Desember 2011, didapatkan bahwa jumlah pasien stroke dengan diabetes mellitus tipe 2 berjenis kelamin perempuan sebanyak 31 orang dari 60 data pasien $(51,67 \%)$. Hal ini relatif sama dengan penelitian yang dilakukan terhadap Incidence of Stroke by Diabetes and Carotid Bruits Status, dimana pada pasien stroke perempuan dengan diabetes memperoleh presentase $3,5 \%$ dengan perbandingan pasien stroke laki-laki dengan diabetes 3,4\%. ${ }^{6}$ Dimana juga pada suatu penelitian di swedia menunjukan adanya kenaikan 13 kali lipat resiko stroke pada perempuan diabetes dan 6 kali lipat pada laki-laki. ${ }^{7}$ Dari hasil pengumpulan data mengenai distribusi penyakit stroke dengan diabetes mellitus tipe 2 berdasarkan usia di bagian Neurologi RSUP Prof. DR. R. D. Kandou Manado periode Januari - Desember 2011, didapatkan bahwa jumlah pasien stroke dengan usia 40 - 59 tahun yaitu terbanyak dengan presentase $50 \%$. Hal ini relatif sama dengan penelitian TwelveYear Incidence of Stroke with and without Diabetes Honolulu Heart Program, Dimana dari 120 orang didapati 118 orang penderita stroke dengan diabetes pada usia 40 - 59 tahun. $^{8}$ Dari hasil pengumpulan data juga mengenai distribusi penyakit stroke dengan diabetes mellitus tipe 2 berdasarkan pemeriksaan kadar gula darah sewaktu (GDS) dan gula darah puasa (GDP) di bagian Neurologi RSUP Prof. DR. R. D. Kandou Manadi periode Januari - Desember 2011, didapatkan bahwa pada kadar gula darah sewaktu terbanyak adala $200 \mathrm{mg} / \mathrm{dl}$ dengan presentase 53,33\% dan kadar gula darah puasa terbanyak adalah $\geq 126 \mathrm{mg} / \mathrm{dl}$ dengan presentase $51,66 \%$, dimana seperti pada penjelasan dalam The American Diabetes Association mengenai kriteria penegakan diagnosis DM tipe 2 adalah kadar gula darah sewaktu (kapan saja, tanpa mempertimbangkan makan terakhir) $\geq 200 \mathrm{mg} / \mathrm{dl}$ dan kadar gula darah puasa (tidak ada asupan kalori selama paling sedikit 8 jam) $\geq 126 \mathrm{mg} / \mathrm{dl}^{5}$

\section{SIMPULAN}

Pada penelitian ini didapati bahwa pasien terbanyak adalah dengan jenis kelamin perempuan, pada kelompok umur 40 - 59 tahun, dan kadar GDS $\geq$ $200 \mathrm{mg} / \mathrm{dl}$, serta GDP $\geq 126 \mathrm{mg} / \mathrm{dl}$.

\section{DAFTAR PUSTAKA}

1. Pinzon R, Asanti L.Awas Stroke Pengertian Gejala Tindakan Perawatan Pencegahan. Jakarta: cvAndi; 2010

2. Kementrian Kesehatan Republik Indonesia. 8 Dari 1000 Orang Di Indonesia Terkena Stroke. [diakses 23 oktober 2012] diunduh dari : http://depkes.go.id/index.php/berita/press- 
release/1703-8-dari-1000-orang-diindonesia-terkena-stroke.html

3. Sudoyo A, Setiyohadi B, Alwi I, Simadibrata M, Setiati S. Buku Ajar Penyakit Dalam. Jakarta: Internapublishing.2009

4. Bethesda Stroke Center. Dislipidemia dan Stroke. [diakses 17 oktober 2012] diunduh dari: http://www.strokebethesda.com/index2.ph p?option.com\%20content\&do\%20pdf=1 \&id=103

5. Utama H. Penatalaksanaan Diabetes Terpadu. Jakarta: Balai penerbit FK.UI. 1995
6. Folsom AR, Eckfeldt JH, Weitzman S, Ma J, Chambless LE, Barnes RW. For the ARIC Study Investigators: Relation of Carotid Artery wall Thickness to Diabetes Mellitus, Fasting Glucose and Insulin body size and physical activity. Stroke 25:66-73.

7. Norris JW, Lachinki V. Stroke Prevention. New York: Oxford University Press; 2001

8. Abbott RD, Donahue RP, Macmahon SW, Reed DM, Yano K: Diabetes and the risk of stroke. The Honolulu Heart Program. Jama 257:949-52 